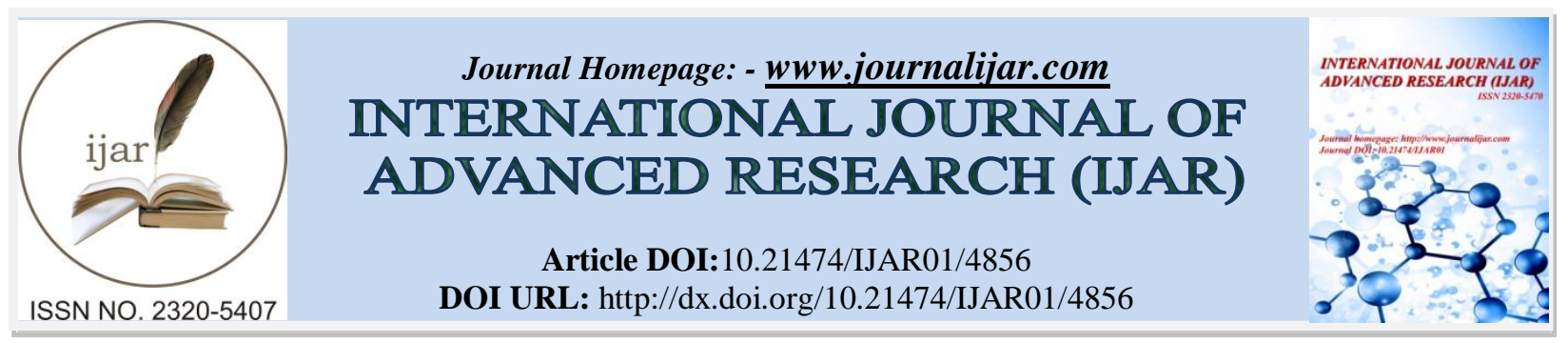

RESEARCH ARTICLE

\title{
BIOASSAY AND IMPACT OF HOUSE HOLD SEWAGE ON SURVIVALITY, GROWTH AND FECUNDITY OF ESOMUS DANRICUS.
}

\author{
Dr. Sanjib Ghoshal. \\ Assistant Professor of Zoology, Bangabasi College, Kolkata-09.
}

\section{Manuscript Info}

Manuscript History

Received: 15 May 2017

Final Accepted: 17 June 2017

Published: July 2017

Key words:-

Sewage, GSI, Aquatic ecosystem, fecundity.

\section{Abstract}

The Darke fish (Esomus danricus) is a freshwater fish. It is one of the most commonly kept aquarium fish. Inland water bodies are subjected to heavy stress due to enormous addition of domestic waste water. The 96 hours static bioassay studies showed LC5-LC90 values ranging from $23.60-67.89 \%$ and $25.67-76.46 \%$ respectively. Exposure to three different dilutions $(5 \%, 50 \%, 90 \%)$ of domestic sewage effluents for 100 days resulted in significant changes $(\mathrm{P}<0.05)$ on fecundity, survivality and GSI of the fish as compared to control. Among physicochemical parameters, significant alterations were noticed in dissolved oxygen (DO), of bottom sediment. The data indicated higher number of fecal coliform and aerobic nitrogen fixers (ANF) and also high heterotrophic bacterial density.

Copy Right, IJAR, 2017,. All rights reserved.

\section{Introduction:-}

We have many small sized fishes in our surrounding water bodies. Many of them are considered to be unwanted for conventional farming. Some of them has a good market demand as ornamental fish. Esomus danricus (Darke fish) is one of them. It has a good market demand as aquarium fish.

Domestic sewage mainly composed of high amount of nitrogenous metabolites, fecal coliform and heterotrophic bacteria. The inland freshwater resources are increasingly subjected to heavy stress due to huge discharge of domestic waste water. It results in deterioration of water quality and effects on ichthyonecton diversity (Choudhury \& Mitra, 2005). Waste water although rich in nutrients but it poses problem such as toxicity to fish and their natural food, bioaccumulation of pesticides, heavy metals and detergents, etc. in fish ( Buras, 1988). It also acts as potential vectors for the transmission of pathogens (Geldrich and Clark, 1996).

A number of studies have been made earlier in India on the use of waste water in aquaculture (Ghosh, et.al., 1988; Jana, 1998). Reports on the toxicological influences of waste water on anchovy fishes and aquatic ecosystem are very limited. Present study was made to evaluate the impact of crude domestic sewage water on a famous aquarium fish Esomus danricus. A study was also made to determine the degree of impact of the sewage water on their exposed ecosystem.

\section{Materials and Methods:-}

Different separate experimental set up were made for this anchovy fish. The experiments were performed in a water reservoir of 500 litter tank for 100 days using three different concentrations of sewage $(5 \%, 50 \%, 90 \%)$. One similar 
arrangement was made without giving the sewage water was treated as control. The total concentrations were calculated and given in three monthly installments. Unchlorinated tap water was used as diluents.

Each tank was stocked with 25 fries of Esomus danricus(length $30.5 \pm 2.3 \mathrm{~mm}$ ) and weight $0.91 \pm 0.48$ gm). Appropriate control was maintained. The control tank fishes were feed with rich bran and groundnut oilcake (1:1) thrice a week @ 2\% of fish biomass. No supplementary feed was given in experimental sets. The fishes were collected from local water bodies and acclimatized for 7 days in the same tank in laboratory. Among them, only healthy fishes were selected for experimental purpose. Fishes were exposed for 96 hours in 20 litter glass aquaria containing 10 litters of tap water. Initial hydrological parameters were measures as $\mathrm{pH}=7.3 \pm 0.1, \mathrm{DO}=2.5 \mathrm{mg} / \mathrm{lit}$, Total alkalinity $246 \mathrm{mg} / \mathrm{lit}$., Hardness $120 \mathrm{mg} / \mathrm{lit}$. Free $\mathrm{Co}_{2} 9.7 \mathrm{mg} / \mathrm{lit}$., Temperature $=24.4^{0} \mathrm{C}$ ).

Crude sewage water was collected from a drain and physicochemical, biological and bacteriological studies were made following the standard methods (APHA, 1985). The values were given in Table-1. The total aerobes were determined by pour plate methods after 48 hours of incubation in sodium caseinatebaird and Parker agar medium Other microbial groups were counted by MPN methods using three tubes. Observation on behavioral changes and mortality of fish were made daily. At the end of the experiment, weight, length, maturity indices (MI) and Gastrosomatic index (GSI) of test fishes were calculated separately for the two exposed fishes. The statistical significance between the treated and control set was calculated by t-test at $5 \%$ level of significance.

\section{Results and Discussion:-}

The physicochemical and microbiological features of collected sewage water used for the present study is given in table-I.

TableI:- Shows physicochemical and microbiological features of collected domestic sewage water.

\begin{tabular}{|c|c|c|c|}
\hline -Parameters & Values & Parameters & Values \\
\hline $\mathrm{pH}$ & 7.3 & Temperature & $29^{0} \mathrm{C}$ \\
\hline DO & $0.4 \mathrm{mg} / \mathrm{lit}$. & Total Alkalinity & $245 \mathrm{mg} / \mathrm{lit}$. \\
\hline Total Hardness & $450 \mathrm{mg} / \mathrm{lit}$ & $\mathrm{HCO}_{3}$ ions & $550 \mathrm{mg} / \mathrm{lit}$. \\
\hline Chloride & $120 \mathrm{mg} / \mathrm{lit}$ & $\mathrm{BOD}_{5}$ & $168 \mathrm{mg} / \mathrm{lit}$. \\
\hline Nitrate & $0.23 \mathrm{mg} / \mathrm{lit}$ & $\mathrm{COD}$ & $277 \mathrm{mg} / \mathrm{lit}$. \\
\hline
\end{tabular}

The present study shows the 96 hours LC5, LC50 and LC95 values of waste water for Esomus danricus was 25.43, 56.43 , and $69.87 \%$ respectively. It was observed that toxic effects of sewage water on the fishes occurred with first 48 hours.

Acute toxicity values of domestic waste water were measured using different species of fish by earlier workers (Gill and Toor, 1975, Sarkar et al., 1993, and Bhowmik et al.,1995). The 96 hours LC50 for fry of Cyprinus carpio was $34 \%$ of domestic waste water as reported by Ghosh et al., (1985).Sarkeret. al., (1993) reported the values as 31-33\% in case of fry of Labeo rohita. The previous data indicated that the exposed fishes in the present study were more resistant than other species of fishes studied earlier.

The present study also indicates the reaction of domestic sewage water on fishes. Fishes exposed to $70 \%$ dilutions (70:30 sewage water: tap water) lost body balance within 5-6 hours for the exposed fishes. The opercular movements of the fishes were reduced and later lethargic movements with frequent surfacing were noticed in the present study.

In $50 \%$ dilution, the fishes were lethargic after about 24 hours of exposure. When the fishes were exposed to lower concentration (10\%) for sewage water, they remain very much active and behaved normally throughout the study. No notable behavioral changes were observed in this fish when exposed to different concentrations of waste water during the whole study period. The survival rate of Esomus danricus was $81 \%$ in $5 \%$ sewage water concentrations, $75 \%$ in $50 \%$ sewage water and $55 \%$ in case of $90 \%$ sewage water concentrations. This shows that Esomus danricus, more or less more tolerant than other previously studied species in experimental conditions. In the present study, the control shows about $95 \%$ survival rate. 


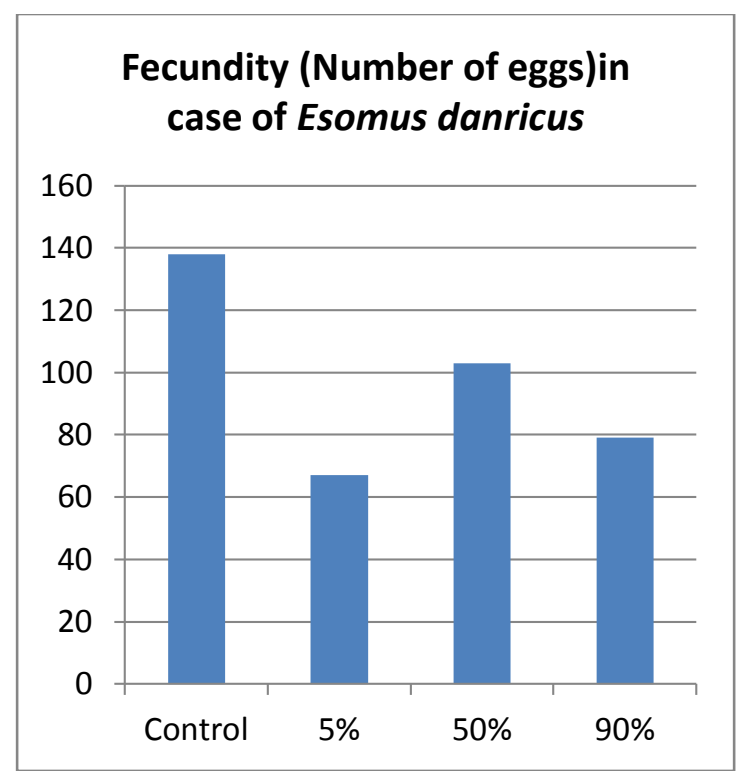

The mean growth increasement of Esomus danricus recorded were 0.03, 0.021 and 0.05 gram per day in 5\%, 50\% and $90 \%$ sewage water respectively. The mean growth of the control was seen $0.01 \mathrm{gm}$ per day. The mean growth increasement of Chanda nama recorded were $0.01,0.02$ and $0.031 \mathrm{gm}$ per day in 5\%,50\% and $90 \%$ sewage water respectively Bayoumi and Khalil (1988). The mean growth of the control was seen 0.016 gm per day in case of Chanda nama Bayoumi and Khalil (1988). The results showed that the fish production in $90 \%$ sewage water was higher in case this fishes, might due to the presence of higher concentrations of organic maters.

These results tally with the observation of Bayoumi and Khalil (1988), and Ghosh et. al., (1988). The fecundity was observed in the present case was 138 \pm 0.08 eggs in control, $138 \pm 0.08$ eggs in $5 \%$ sewage water, $103 \pm 0.63$ eggs in case of $50 \%$ sewage water while $79 \pm 0.59$ eggs in case of $90 \%$ sewage water. These results slightly contradict with the earlier observations. Earlier observations showed slight increasement of fecundity in sewage water in case of Oreochromes mossambicus (Sarkar, et. al., 2000).

The gastrosomatic index (GSI) in this case was $5.75 \pm 0.67$ in case of control. $5.23 \pm 0.09$ in case of $5 \%$ sewage water, $6.66 \pm 0.79$ in case of 50\% sewage water and $6.18 \pm 0.56$ in case of $90 \%$ sewage water. In this case the GSI remained more or less unchanged in three different experimental conditions in comparison to the control. Therefore, from the present study it was revealed that the target fish shows good growth rate in $90 \%$ sewage water but it can survive for considerable days and shows good fecundity in case of medium containing $50 \%$ sewage water.

In case of Esomus danricus

\begin{tabular}{|c|c|c|c|c|}
\hline & $\begin{array}{c}\text { Control } \\
0 \% \text { Sewage water }\end{array}$ & $\begin{array}{c}5 \% \text { Sewage } \\
\text { water }\end{array}$ & $50 \%$ Sewage water & $90 \%$ Sewage water \\
\hline Survivality & $95 \pm 0.61 \%$ & $81 \pm 0.05 \%$ & $75 \pm 0.45 \%$ & $50 \pm 0.34 \%$ \\
\hline Growth rate (gm/day) & $0.01 \pm 0.002$ & $0.03 \pm 0.001$ & $0.021 \pm 0.002$ & $0.05 \pm 0.001$ \\
\hline Fecundity (Number of eggs) & $138 \pm 0.08$ & $67 \pm 0.04$ & $103 \pm 0.63$ & $79 \pm 0.59$ \\
\hline GSI & $5.75 \pm 0.67$ & $5.23 \pm 0.09$ & $6.66 \pm 0.79$ & $6.18 \pm 0.56$ \\
\hline
\end{tabular}

\section{References:-}

1. APHA (American Public Health Association), American water works association and water pollution control federation, 1985. Standard methods for the examination of water and waste water, sixteenth Ed. Am. Pub.Hlth. Assoc. Washington, USA.

2. Bayoumi, A.R., \& Khalil, M.T., 1988. Tilapia fisheries in Lake Manzala, Egypt, Bull. Inst. Occan, Fisheries, 14:87-99. 
3. Bhowmik, M.L., Pandey, B.K. \& Sarkar, U.K. 1995. Influence of domestic sewage on fish and incidence of microbial population. In: P.C. Thomas (ed) current and emerging trends in aquaculture, Daya publishing house, New Delhi. Pp: 35-38.

4. Buras. N., 1988. Public health guidelines for sewage fed fish culture. In A.G. Jhindranet.al., $2^{\text {nd }}$ edition, pp 7079.

5. Choudhury, A.C. \&Mitra, A., 2005. Effect of sewage water on some of the indigenous fishes in freshwater reservoirs. Ecol \& Envs., 23(3): 234-238.

6. Geldrich, E.E., \& Clark. N.A, 1996. Bacterial pollution indicates in the intestinal trout of freshwater fish. Appl. Microbiol., 14:429-437.

7. Ghosh, A., Chattopadhyay, G.N. And Chakraborty, P.K. 1988. Environmental and sanitary aspects of wastewater recycling for productive use. In A.G. Jhindranet al $2^{\text {nd }}$ Edition.Pp: 35-41.

8. Ghosh, T.K., Rao, A.V.J., Joshi, M.W., 1985. Settled sewage for pisciculture. AsianEnviron., 7: 31-35.

9. Gill, H.S., \&Toor, H.S., 1975. Toxicity of the sewage effluent of the Ludhiana City to fish in BudhaNullah. Ind.J.Ecol., 2(1): 87-93.

10. Jana, B.B., 1998. Sewage feed aquaculture: The Calcutta model. Ecol. Eng., 11:73-85.

11. Sarkar, K.P., Pandey, B.K., \&Sarkar, U.K., 2000. Hydrological and bacteriological properties of some sewage water collected from different parts of Bhubaneswar. Appl. Ecol., 9(3): 45-51.

12. Sarkar, U.K., Pandey, B.K. \&Bhowmik, M.L., 1993. Toxicity of domestic sewage on fry ofCatlacatla,Labeorohita, Environ. Ecol., 11(2): 439-441. 